\title{
Lusotopie
}

Recherches politiques internationales sur les espaces

issus de l'histoire et de la colonisation portugaises

$\mathrm{XV}(1) \mid 2008$

Indiens du Mozambique et d'Afrique orientale

\section{Global Goans. Migration Movements and Identity in a Historical Perspective}

Goanais du monde. Mouvements migratoires et identité dans une perspective historique

Goeses globalizados. Movimentos migratórios e identidade numa perspectiva histórica

\section{Margret Frenz}

\section{OpenEdition}

\section{Journals}

Electronic version

URL: http://journals.openedition.org/lusotopie/833

ISSN: $1768-3084$

Publisher:

Association des rechercheurs de la revue Lusotopie, Brill, Karthala

Printed version

Date of publication: 30 June 2008

Number of pages: 183-202

ISSN: 1257-0273

Electronic reference

Margret Frenz, "Global Goans. Migration Movements and Identity in a Historical Perspective »,

Lusotopie [Online], XV(1) | 2008, Online since 09 March 2016, connection on 02 May 2019. URL : http:// journals.openedition.org/lusotopie/833 


\section{GLOBAL GOANS. MIGRATION MOVEMENTS AND IDENTITY IN A HISTORICAL PERSPECTIVE}

Reflecting on the often diffuse use of the concepts transnationalism and translocality this paper argues that the terms need to be historicised. The case study of migration movements of Goans across the Indian Ocean and beyond it illustrates the argument that the temporal layers of translocal, transnational and global phenomena cannot be conceptualised without taking into account the characteristics of the different locations concerned. In a further step, it is argued that specific space time relations are correlated with specific forms of social interaction. The identity of Goans was constituted within the translocal, transnational, and global temporal layers in the context of their twice migration. Social institutions such as the church, the club, and schools played an important role in this process. Arguably, the connection between migration movements and identity formation can be applied to other migratory groups who shared a similar history.

\section{Goanais globalisés. Mouvements migratoires et identité dans une perspective historique}

L'utilisation souvent diffuse des concepts de transnationalisme et de translocalité, souligne d'abord le besoin de replacer ces termes dans leur contexte historique. L'étude de cas des mouvements migratoires des Goanais dans l'océan Indien et au-delà, illustre l'argument selon lequel les strates temporelles des phénomènes translocaux, transnationaux et mondiaux ne peuvent être conceptualisées sans prendre en considération les caractéristiques des différents lieux concernés. L’article développe ensuite l'idée d'une corrélation entre les relations spatiotemporelles et des formes spécifiques d'interaction sociale. L'identité des Goanais s'est constituée à l'intérieur de couches temporelles translocales, transnationales et mondiales dans le contexte de leur double migration. Des institutions sociales telles que l'église, le club et l'école ont joué un rôle important dans ce processus. On peut suggérer qu'il serait possible d'appliquer le lien entre les mouvements migratoires et la formation de l'identité à d'autres groupes migrants ayant connu une histoire semblable.

\section{Goeses globalizados. Movimentos migratórios e identidade numa perspectiva histórica}

Ao reflectir sobre a utilização frequentemente difusa dos conceitos de transnacionalismo e translocalidade, este artigo defende a ideia de que estes termos necessitam de ser inseridos num contexto histórico. O estudo de casos dos movimentos migratórios dos Goeses pelo Oceano Índico e mais além, ilustra o argumento de que as camadas temporais dos fenómenos translocais, transnacionais e globais não podem ser conceptualizados sem ter em conta as características dos diferentes lugares relacionados. Uma etapa seguinte defende a ideia de correlação entre as relações espácio-temporais e formas específicas de interacção social. A identidade dos Goeses constituiu-se no interior de camadas temporais translocais, transnacionais e mundiais no contexto da sua dupla migração. As instituições sociais como a igreja, o clube e as escolas desempenharam um papel importante neste processo. É possível aplicar uma relação entre os movimentos migratórios 
e a formação da identidade a outros grupos migratórios que viveram uma história semelhante.

\section{"Zeitschichten' verweisen, wie ihr geologisches Vorbild, auf mehrere Zeitebenen verschiedener Dauer und unterschiedlicher Herkunft, die dennoch gleichzeitig vorhanden und wirksam sind. Auch die Gleichzeitigkeit des Ungleichzeitigen, eines der aufschlußreichsten Phänomene, wird mit "Zeitschichten" auf einen gemeinsamen Begriff gebracht."}

$\mathrm{T}$ Throughout the last decade, 'transnational' perspectives have featured prominently in historiographical discourse when analysing the movement of goods, people, and ideas. It has become fashionable to write about transnational flows, transnational migration, transnational villages, and transnational history. However, the manner in which scholars of various disciplines engaging in 'transnationalism' have conceptualised this term raises several issues. From the historian's point of view, the term 'transnationalism' tends to be used statically. A second critical observation is the implicit reference of the term to nations or nation-states. The phenomenon of the nation-state, however, emerged rather late in history. Consequently, the concept 'transnationalism' is only appropriate for the analysis of historical events and processes of the recent past, focusing on late nineteenth century European, and twentieth century Asian and African history ${ }^{2}$.

The current paper offers a fresh perspective on transnationalism. It will be shown that to arrive at a more meaningful concept of transnationalism, this concept needs to be historicised, i.e. it must be set in a specific place at a specific time. Here I follow Koselleck's argument to call for a temporal differentiation of Fernand Braudel's longue durée. Like geological strata, temporal strata are made up of manifold layers, which may occur simultaneously. They overlap each other, and at times appear in tension to each other ${ }^{3}$. Time in this understanding is neither linear nor circular. Rather, it is constituted by (individual) experience and

${ }^{1}$ R. Koselleck, Zeitschichten. Studien zur Historik, Frankfurt, Suhrkamp, 2000, 399 p.: 9. "Like geological strata, 'temporal layers' refer to several temporal levels of various duration and different origin, which are nevertheless existent and effective at the same time. Equally, one of the most instructive phenomena, the simultaneity of the not simultaneous, is conceptualised in a common term 'temporal layers' ".

${ }^{2}$ See for instance, the ongoing discussion on 'transnational' history, or the 'transnational turn': C.A. BAyly, et al., "AHR Conversation: On Transnational History", The American Historical Reviewe, 111 (5): 1141-1464, 2006; P. Levitt, The Transnational Villagers, Berkeley-Los Angeles-London, University of California Press, 2001, 281 p.; J. Osterhammel, "Transnationale Gesellschaftsgeschichte: Erweiterung oder Alternative?", Geschichte \& Gesellschaft 27 (3), 2001: 464-479; S. Vertovec \& R. Cohen, (eds), Migration, Diasporas and Transnationalism, Cheltenham-Northampton, Edward Elgar, 1999: 9; A. AppaduraI, "Sovereignty Without Territoriality. Notes for a Postnational Geography", in P. Yaeger (ed.), Geography of Identity, Ann Arbor, University of Michigan Press, 1996: 40-58; N. Glick Schiller \& L. Basch \& C. Blanc-Szanton, "Transnationalism: A New Analytical Framework for Understanding Migration", Annales New York Academy of Sciences, 645, 1992: 1-24.

${ }^{3}$ R. Koselleck, Zeitschichten..., op. cit.: 12, 15. 
life cycle rituals ${ }^{4}$. Thus, 'translocal', 'transnational' and 'global' phenomena can be understood as temporal layers of migration movements. The different migration movements of Goans across the Indian Ocean and beyond are taken as a case study to argue that these temporal layers cannot be conceptualised without taking into account the characteristics of the different locations. Space and time, as not only Koselleck has noted, are inextricably linked. The aim of this article is to show how the complex combinations of 'intersecting local contexts' ${ }^{5}$ and interwoven temporal layers shaped the construction of Goan identity in the course of a century.

This article analyses the migration, institutionalisation and circulation of Goans. Their twice migration, first from West India across the Indian Ocean to East Africa and then from East Africa to various countries in the northern hemisphere or so-called 'western world', offers rich material for grounding the conceptual ideas put forward in this paper in empirical research ${ }^{6}$. Reviewing Goan migration patterns gives us an idea of the geographical area covered, i.e. their spatial extension. This is followed by an analysis of their institutionalisation as communities in new local contexts, particularly in British East Africa, namely Zanzibar, Tanganyika, Kenya and Uganda ${ }^{7}$. Both movement and institutionalisation are presented as distinct features of the translocal temporal layer. In a third step, I will pursue the migration movements of Goan families to places far beyond the Indian Ocean, as well as their adjustment to either new local contexts or drastically changed political, economic and social conditions in familiar surroundings. These developments are ascribed to the transnational and global temporal layers. Finally, it will be argued that this approach to migration shows the historical dimension of these movements.

\section{Goans on the Move: Early Patterns of Migration}

In the late nineteenth century, the Indian Ocean region constituted a lively trading zone. Gujaratis, Punjabis, Hadramis and other traders crisscrossed the Indian Ocean to undertake the exchange of goods. One of the most attractive ports of call was Zanzibar $^{8}$. Between the 1850 s and the 1900 s, the modes of transport changed

${ }^{4}$ R. KoselLeck, ibid: : 20-26.

${ }^{5}$ R. Harms, The Diligent. A Voyage Through the Worlds of the Slave Trade, New York, Basic Books, 2002, 466 p.: xix.

${ }^{6}$ This paper is based on c. 220 interviews I conducted and research in archives and libraries in Goa, Zanzibar, Tanzania, Kenya, Uganda, Germany, the UK and Canada in the years 2002 to 2007.

${ }^{7}$ In the current paper, I focus on British East Africa, i.e. Zanzibar, Tanganyika (later Tanzania), Kenya and Uganda. Goans also migrated to Portuguese East Africa, i.e. Mozambique, and Portuguese West Africa, i.e. Angola, which constitute a future strand in my research.

${ }^{8}$ Cf. M. Frenz, et al., 2005, "Neuere Literatur zum Indiaschen Ozean - eine kritische Würdigung", Periplus. Jahrbuch für außereuropäische Geschichte, Münster, 15: 141-172. See the latest publications on the Indian Ocean region with particular emphasis on India's role in it: S. Bose, A Hundred Horizons. The Indian Ocean in the Age of Global Empire, Cambridge (Mass.)-London, Harvard University Press, 2006, 333 p. and T.R. Metcalf, Imperial Connections. India in the Indian Ocean Arena, 1860-1920, Berkeley-Los Angeles-London, University of California Press, 2007, 264 p. On Hadrami traders see E. Ho, The Graves of Tarim. Genealogy and Mobility across the Indian Ocean, Berkeley-Los Angeles-London, University of California Press, 2006, 379 p. A bit further south along the western Indian Ocean rim, Goans seem to have migrated to Mozambique as early as 
considerably. The introduction of the steamship, which accelerated the pace of travel and the volume of trade, was the most significant change. Therewith social interaction across the Indian Ocean was condensed ${ }^{9}$. Indian seamen and traders were actively involved in these activities, and some of them decided to settle in East Africa ${ }^{10}$.

Documentary evidence of the first Goan 'pioneers' in the second half of the nineteenth century can be found in Zanzibar. Trade was encouraged by local rulers, in Zanzibar by the Sultan. Towards the end of the century, the Imperial British East Africa Company (IBEAC) recruited Goans to work on the construction of the railway line which had got under way in 1895. Goans were likewise asked to take up jobs in the administrative units of the colonial government. In 1895, the IBEAC territories were taken over by the British Government, which continued to recruit Goans. The regulative mechanisms used in their recruitment differed to those for other groups, such as Indian soldiers or indentured labourers. In contrast to the latter groups, most Goans migrated voluntarily and were employed in a variety of professional occupations. As a rule, they paid for their own passage $^{11}$, and their emigration was monitored by the Indian emigration authorities to a lesser extent than that of indentured labourers.

The construction of the Uganda Railway brought about a significant increase in the number of people hired in India to work in East Africa. Moreover, the establishment of towns and cities along the railway line, such as Nairobi in 1907, stimulated the emergence of an urban service sector ${ }^{12}$. In turn, this afforded many

the 16th century. They worked in various fields, such as the military service, the administration, agriculture, and later on, in medicine and law. See S. KARnik, 1998, "Goans in Mozambique", Africa Quarterly, 38, 3: 95-118, and A. Pereira De Lima, Cartograma da penetração goesa em Moçambique: séculos XVI a XIX, Lourenço Marques, [1972], 23 p. It appears that the Portuguese did not recruit Goans as systematically as did the British. The records in the Goa State Archives suggest a decrease in migration to Mozambique once Goans moved to British East Africa in high numbers (Goa State Archives, Series of passaportes, nos. 10513 to 10547). Personal communication Simon, Goa, December 2002.

${ }^{9}$ J.-G. Deutsch \& B. Reinwald, Space on the Move. Transformations of the Indian Ocean Seascape in the Nineteenth and Twentieth Century, Berlin, Klaus Schwarz Verlag, 2002, 89 p. ("Arbeitshefte Zentrum Moderner Orient" 20).

${ }^{10}$ See J.S. Mangat, A History of the Asians in East Africa, c. 1886-1945, Oxford, Clarendon Press, 1969, 216 p.; R.G. Gregory, South Asians in East Africa. An Economic and Social History, 1890-1980, Boulder-San Francisco-Oxford, Westview Press, 1993, 410 p.; C. Salvadori, Through Open Doors. A View of Asian Cultures in Kenya, Nairobi, Kenway Publications, 1989; C. Salvadori, We Came in Dhows, 3 vols., Nairobi, Paperchase Kenya, 1996. For a comparative perspective, see P. BнAchu, Twice Migrants. East African Sikh Settlers in Britain, London-New York, Tavistock Publishers, 1985, 205 p.; P. Herzig, South Asians in Kenya. Gender, Generation and Changing Identities in Diaspora, Münster, Litverlag, 2006, 299 p.; Goans were particularly attractive as personnel to British steam navigation companies, because as Catholics they could cook and serve any dish without restrictions. Apparently, Goans were sought after recruits for attending to passengers and crews in the so-called 'saloon'departments aboard ships. In port cities such as Bombay, Goan stewards and chefs often lived in commonly organised quarters, known as kurs or as 'Goanese Seamen's Clubs'. See R. VisRam, Asians in Britain. 400 Years of History, London-Sterling (Virginia), Pluto Press, 2002, 488 p.

${ }^{11}$ R. Gregory, South Asians in East Africa..., op. cit.: 17, 187.

12 The railway was completed between Mombasa and Nairobi in 1899; in 1902 it reached Nakuru and in 1928 Kampala. See M.F. Hill, Permanent Way. The Story of the Kenya and Uganda Railway. Being the Official History of the Development of the Transport System in Kenya and Uganda, vol. I, Nairobi-Kampala-Dar-es-Salaam, East African Literature Bureau, 1976, 591 p. 
Goans with hitherto unexpected job opportunities and the prospect of 'doing well'. For the majority of migrants, promising income opportunities were the key reason to leave Goa. On the one hand, farming in Goa did not provide the means to 'do well'13. On the other side, the Portuguese, whilst not inclined to develop Goa, encouraged education, at least at primary school level. A handful of Goans managed to get work in the administrative service of the Portuguese colonial government, but the well-educated in particular had difficulty in finding suitable work ${ }^{14}$. Today, many of my interviewees maintain the notion that they and their forefathers left Goa to look for 'greener pastures' elsewhere ${ }^{15}$.

As alluded to above, the recruitment campaign of the British government in East Africa, with specific reference to the construction of the Uganda Railway and the establishment of a cheaply run colonial administration, proved to be highly attractive to these Goans. What began as a migrant trickle developed into a steadily increasing flow. It is difficult to establish exact figures for the early years of migration to East Africa. However, as evidenced in the available census and other scattered registers in colonial records, it seems that Goans constituted up to $10 \%$ of the resident Indian population in East Africa ${ }^{16}$. For the years 1911 to 1948, Goans were listed as a separate category in the census returns. As of the 1950s, the number of Goans entering to East Africa increased further to an estimated $30,000^{17}$, but were listed for census purposes in the category 'Asians', 'Portuguese', 'Indians', or 'Christians'.

\begin{tabular}{cccccr}
\hline $\begin{array}{c}\text { Goans in East } \\
\text { Africa }\end{array}$ & Kenya & Uganda & Zanzibar & Tanganyika & Total \\
\hline 1911 & 1136 & & $440^{*}$ & $656^{* * *}$ & \\
1921 & 2431 & 474 & 869 & 798 & 4572 \\
1928 & 3131 & 929 & 954 & 1445 & 6459 \\
1931 & 3979 & 1124 & 1004 & 1722 & 7829 \\
1938 & 6205 & 1257 & 871 & 1839 & 10172 \\
1948 & 7159 & 1448 & 681 & 2006 & 11294 \\
\hline
\end{tabular}

Source: Compiled from the 1910, 1911, 1913, 1921, 1928, 1931, 1928 and 1948 Census of Kenya, Census of Tanganyika, Census of Uganda, and Census of Zanzibar. For Uganda in 1948, the percentage of Goans among the 'non-native' population of Uganda was $3.5 \%$, while $82.4 \%$ of the 'non-native' population were classified as Indians and $8.4 \%$ as Europeans.

* Year 1910; ** Year 1913.

13 S.V. Mascarenhas-Keyes, Migration and the International Catholic Goan Community, London, School of Oriental and African Studies, Ph.D. thesis, 1987: 26.

${ }^{14}$ J.M. Nazareth, Brown Man, Black Country. A Peep into Kenya's Freedom Struggle, New Delhi, Tidings, 1981: 20; Interview with Thomas, Goa, December 2002 (the names of all interviewees have been changed in order to protect their anonymity).

15 " [...] these Goans who have got nothing in Goa went in search for greener pastures. People in Goa who never - had anything - went to where the grass is greener." Interview with Leopold, UK, April 2005.

${ }^{16}$ See also C. Salvadori, Through Open Doors..., op. cit:: 7.

17 B.G. D’SouzA, Goan Society in Transition. A Study in Social Change, Bombay, Popular Prakashan, 
Goan migration movements have a specific spatial pattern. In the mid-nineteenth century, Zanzibar appears to have been the most attractive place to stop and settle. The subsequent years, particularly the 1890s and early 1900s, saw a shift towards the East African mainland, i.e. to locations such as Mombasa, and Dar-es-Salaam further south. People gradually began to move from the coast to the interior - a movement initiated and intensified by the construction of the railway line. This movement between localities situated along the Indian Ocean rim became a key characteristic of the translocal time layer. Linked to this migration was a parallel process of settling in which had got under way at the same time.

\section{Across the Indian Ocean: Settling Down in East Africa}

With regard to occupations, Goans adapted to the respective local economic conditions. Their institutionalisation in this new East African cultural context manifested itself in the creation of a social infrastructure and the (re-)construction of social and material practices, such as the founding of clubs and the building of schools and churches. However, this was not purely a process of (re-)producing familiar practices but rather a creative selection of the cultural and social elements to be kept alive and a conscious or unconscious discarding of others, all of which was accompanied by a corresponding adjustment to the new situation in East Africa.

\section{Professional Life}

In the early years of Goan migration to East Africa, the majority decided to go into business. In Zanzibar, one of the principal trading centres in the western Indian Ocean, the most prominent retailers between the 1860s and 1900s were of Goan origin. In 1894, 119 Goans were listed as either shop owners or employees of Goan enterprises, or as officers in the Sultan's government in Zanzibar. Several Goans who had established businesses in Zanzibar opened branches in Dar-es-Salaam, Bagamoyo, Tanga, Kilwa, and Pangani. These enterprises, the largest of which had thirty-one employees ${ }^{18}$, were usually wholesale retailers, frequently combined with tailoring and shoemaking facilities ${ }^{19}$. Having established a reputation as excellent chefs and stewards on board ship, it is not surprising that the majority of hotels, restaurants and bars on the island were Goan ${ }^{20}$. Bakeries

18 The British Consular General prepared a list of Europeans and Goans resident in Zanzibar. However, it is not clear whether the list is complete, Zanzibar National Archives, AB33/10.

19 The most prominent amongst them were C.R. de Souza, L.M. de Souza, Messrs Souza Junior \& Dias, and Messrs Peres \& Pereira. C.R. de Souza, born in Goa on 7 February 1839, established his business in Zanzibar in 1865 (Interview with Humphrey, Tanzania, July 2005). The advertisement announcing his offers in the Zanzibar Official Gazette is proudly titled "A Diploma of Honour with Gold Medal awarded from H.H. Seyyid Barghash-Bin-Said for Enterprise in 1880'" (Zanzibar Official Gazette, March 1892).

${ }^{20}$ For instance, the Lusitania on Cathedral Street, the Japanese Bar, later called the English Bar, the Metropolitan Hotel on Sokomohogo Street, Hotel Carmen, and Hotel Coutinho (Zanzibar Official Gazette, May 1896, September 1903; interviews with Benedict, Bruno, Humphrey, Jessica, Tanzania, July 2005). 
and photography studios are further examples of business enterprises. Goan bakeries were highly reputed, especially in the $1890 \mathrm{~s}^{21}$. It was around this time that a Goan photographer opened the first photography studio in Zanzibar. Within a few years, several Goan photographers were competing with each other on the island. With their postcard series of the people and landscapes of Zanzibar, they contributed to shaping the perception and visualization of Zanzibar in the wider world in the initial decades of the twentieth century ${ }^{22}$. By the 1950 s and early 1960s, thirty to forty Goan tailors had established workshops along the main shopping roads in Zanzibar. In order to cope with tailoring orders these entrepreneurs usually employed a number of other Goan tailors, frequently relatives or neighbours from their home. Many of them were specialised, such as ladies or gents outfitters. In Uganda, the garment known as gomesi was designed by A.G. Gomes, a Goan tailor who had probably opened his shop in Kampala in the late nineteenth or early twentieth century. According to an ex-Kampala tailor, the design was a combination of the Indian sari and the local pusuti ${ }^{23}$.

Apart from flourishing business enterprises in Zanzibar, Goans were employed in the Sultan's government, and in later on in the British administration throughout British East Africa ${ }^{24}$. For the most part they worked as 'clerical officers' and have repeatedly been characterised as 'the backbone of the administration', particularly in the early days of British colonial rule ${ }^{25}$. Their numbers rose steadily; around 1911, for example, about 1200 Indian clerical officers worked in the Kenyan and Ugandan administrations. As pointed out above, a significant number were Goans ${ }^{26}$. In particular, the treasury and the audit department were completely in 'Goan hands'. In the remoter districts, they frequently ran the local administration on their own ${ }^{27}$. The self-perception of the Goans who worked in the British administration between the 1930s and the 1960s becomes apparent in the following statement by a former administrative officer:

"The majority were in the civil service and the British government were more inclined to have Goans in their departments because they knew they were loyal and hard

${ }^{21}$ A.C. D'Souza opened the Africa Bakery in Sokomohogo in 1900. He received a gold medal for his variety of breads in 1905 (interviews and personal communications with Jessica, Benedict, Tanzania, July 2005). There were about three Goan bakeries in Stone Town (interviews with Benedict, Bartholomew, Jessica, Tanzania and UK, July and September 2005).

${ }^{22}$ A.P. de Lord opened the first photography studio, followed by E.C. Dias, A.C. Gomes \& Co., and the Coutinho Brothers (Zanzibar Official Gazette, August 1892); see M. Frenz, "Goan Photographers and Their Sujets in Zanzibar, c. 1865 to 1960", ms., University of Oxford, June 2007.

${ }^{23}$ Interviews with Nathan, Goa, January and February 2006, and Maria, Canada, August 2007.

${ }^{24}$ See also J.S. Mangat, "The Immigrant Communities (2): The Asians", in D.A. Low \& A. Sмiтн (eds), History of East Africa, vol. III, Oxford, Clarendon Press, 1976: 467-488.

${ }^{25}$ C. Salvadori, Through Open Doors..., op. cit.: 311.

${ }^{26}$ According to R. Gregory, South Asians in East Africa..., op. cit.: 191 and J.S. Mangat, A History of the Asians..., op. cit.: 76.

27 See M. Maciel, Bwana Karani, Braunton (Devon), 1985, 262 p. 
working and they knew their English language better than the others. So they used to hold all the good positions in the government service." ${ }^{28}$

The administration was organised in a three-tiered system along ethnic lines, with Europeans in the top tier, African staff in the lower ranks and Indians in the middle. The potential for conflict was inherent in this system. Most of the positions in the middle ranks of the administration prescribed for 'Asians' by the colonial government were held by Goans. They were subject to resentment and criticism from both sides. Goan perception of this situation suggests that the colonial policy was by and large accepted. It is described by some interviewees as follows: "It was like a sandwich. See, we were in the middle, so [our life] was not so good, but not so bad"29. The attraction of the administrative service, apart from a regular salary, a permanent position, and the prospect of promotion and other benefits, was the prescribed six month 'home' or 'long' leave every four years. This in turn allowed many Goans to visit Goa on a regular basis and maintain links with families and friends. Particularly in the early years of the twentieth century, children were left with the grandparents in order to receive adequate schooling. In other instances, elderly widowed parents were taken with the 'young' family to East Africa.

Besides working in the various government departments, Goans trained and worked as doctors, nurses, and lawyers ${ }^{30}$. The changing pattern in occupations taken up by Goans is a reflection of the changes that occurred within two to three generations. So-called 'white collar' jobs implied a higher status than being employed in a workshop, for example, even if the latter meant a higher income. Over time, Goans were drawn into certain professional categories that allowed them to occupy prestigious ranks and fit into the existing socio-economic and political structure in East Africa.

\section{Social Life}

In the early decades of Goan migration to East Africa, the community gradually established its 'own' institutions or social infrastructure, the most prominent of which were the 'clubs' and associations that became the social centre. The first association was founded in Mombasa in 1901 and was known as the 'Goan Reading Room'. ${ }^{31}$ In time, Goan clubs and associations were established all over

${ }^{28}$ Interview with Bartholomew, UK, March 2004. The Handbook for East Africa, Uganda and Zanzibar of 1904 describes the Goan community in similar terms - as 'loyal' and 'efficient'.

${ }^{29}$ Interview with Luisa, Marc, UK, April 2005. Arguably, the Goans in East Africa - British and Portuguese - constituted a 'subaltern elite' migratory group. Their 'middling' status was prescribed by the colonial government, and they perceived themselves in a similar way. However, tension between colonial policy, self-perception and reality always existed. For a discussion on 'subaltern elite', see K. Visweswaran, "Small Speeches, Subaltern Gender: Nationalist Ideology and Its Historiography", in S. Amin \& D. Chakrabarty (eds), Subaltern Studies IX. Writings on South Asian History and Society, New Delhi, Oxford University Press, 1996: 83-125.

30 The Goa Medical College was established in 1842. Some of its graduates migrated to East Africa.

${ }^{31}$ Later known as the Goan Institute Mombasa. 
East Africa, particularly in the larger cities such as Nairobi, Kampala, Dar-es-Salaam and Zanzibar Stone Town ${ }^{32}$. Two types of social institutions can be identified: the clubs which served as meeting places, and overarching community associations that catered for the entire community in the sense of a social welfare system.

The Goan club scene, however, cannot be described as 'harmonious' or homogenous. Several clubs flourished in the major cities. In Nairobi, for instance, the Goan Institute, the Goan Gymkhana, the Goan Railway Institute, and the St. Francis Tailoring Society attracted different sections of the community. In Kampala, the members of the Goan Institute and the St Francis Tailoring Society, which were situated on two hills in town, rarely made exchange visits or invited each other to special occasions. From the available records and the interviews conducted, it would seem that caste played a role in decisions about membership of a particular club. In the early decades of the twentieth century, for instance, aspiring members were interviewed by the board of the club and assessed according to their education and profession. In the $1950 \mathrm{~s}$, social fault lines in the community became increasingly blurred. In contrast to the clubs, the umbrella organisation, known either as the Goan Overseas Association or the Goan Community, aimed at reaching out to all Goans irrespective of club membership. Goans were automatically a member of this overarching organisation, whose objective was to improve educational standards and provide other facilities for the community on a more general level. The club landscape in Uganda, Kenya, Tanganyika and Zanzibar differed to a certain degree. Goans adapted to the specific local contexts in these countries, carving out distinct spaces that could be termed the Zanzibari Goan space, the Tanganyikan Goan space, the Ugandan Goan space and the Kenyan Goan space.

According to the majority of my interviewees, the clubs played a major role in their social and private lives. In numerous cases, men frequented 'the club' on an almost daily basis, either for sports or to have a chat over a drink. At weekends, entire families would come to the club for a dance, a party and most importantly, sports. All major institutes had their own sports grounds, where tournaments were held regularly. The most popular sport was hockey, followed by badminton, cricket, tennis, table tennis, billiard and others. Men's and women's teams took part in the sports competitions, which linked the clubs in different cities on a regular basis. Not only did these events connect the Goan spaces in East Africa, they also established links between the various communities living in one particular location. Within a city, tournaments created a common ground for interaction between the teams of Goan, Indian, African, and European clubs ${ }^{33}$.

${ }^{32}$ Goan Institutes were established in the following years: Zanzibar 1904, Nairobi 1905, Kampala 1910, Dar-es-Salaam 1919. More were to follow in other cities. The Goan Community Tanganyika was already founded in 1892. A similar development can be observed in Mozambique: The 'Instituto Goano' in Lourenço Marques was established in 1905, the 'Associaçao Beneficencia' in Beira in 1908. C.F. Andrews mentions the 'Cabinete de Leitura de Beira' and his pleasant experience of using its library and reading room when he visited Beira in 1920. See brochures of the various institutes, and M. Frenz, "Clubbing in East Africa", ms., University of Oxford, December 2007.

${ }^{33}$ The M.R. de Souza Gold Cup was a desired and vigorously contested trophy in hockey competitions (interview with Robert, UK, November 2004; personal communications Sara and Susi, Tanzania, July 2005 and June 2006). 
Last but not least, the church played a highly significant role in Goan community life. The vast majority of the Goans who migrated to East Africa were Catholic. Many of my interviewees described themselves as 'staunch Catholics' and went to mass every Sunday. Only a minority of respondents spoke openly of their sceptical attitude towards religious matters. Christenings, first holy communions, weddings and funerals were occasions where the congregation met regularly. Quite a number of East African Catholic churches were built with generous Goan support, such as the St Francis Xavier Church in Nairobi, and Christ the King Cathedral in Kampala, to name but a few. Another aspect of church life were the feasts in honour of patron saints linked to village churches in Goa. People who originally came from the village of Saligao, for example, celebrated Mãe de Deus on the first Sunday in May, while those from Navelim celebrated the feast of their patroness Our Lady of Rosary in mid-November. The feast of St Francis Xavier was celebrated throughout East Africa on the 3rd of December each year ${ }^{34}$.

\section{Interface between Social and Political Life}

In the long run, the most influential Goan institutions in East Africa were the schools at kindergarten, primary, and secondary level. Education for the younger generation ranked high on the priority list of parents. The political environment of racial segregation made it necessary to establish different schools for members of different communities. Only Europeans, for example, were given access to European schools. The Goan community therefore applied to the respective governments in East Africa for funds to build schools and employ qualified teachers. However, government money was forthcoming only when the community itself invested money. Quite a number of nursery schools were established by Goan women in their own homes in the 1920s and 1930s, prior to the establishment of formal schools such as the Goan Community Primary School at Mombasa $(1932)^{35}$. A well-known Goan secondary school in Nairobi, the Dr. Ribeiro Goan School, was built with grants from the British and Portuguese governments as well as with community subscriptions, and opened in $1940^{36}$. These schools were open to all Goan children irrespective of their parents' background, an indication, that the importance of prevailing caste or village identities declined.

From the 1920s on, many Goans - and increasingly, women - opted for the teaching profession. The general trend of establishing schools in East Africa, and the construction of Goan schools, was accompanied by a strong demand for teachers. Goans taught primarily in Indian, Goan, and Aga Khan schools. The Goan school in Kampala was built on the initiative and with major financial donations by Norman Godinho, a highly successful entrepreneur whose activities included the management of Speke Hotel and - most famously - the Kampala Playhouse,

${ }^{34}$ Goans working in the administration were given a half day off work to be able to attend the church service (Kenya National Archives, MOH/1/1823).

35 The school, now known as Sacred Heart School, celebrated its Platinum Jubilee in August 2007.

${ }^{36}$ For the process of establishing the school and receiving government funds, see Kenya National Archives XK/3/1. 
known as Norman Cinema. To facilitate students from locations outside Kampala to study at the school, a hostel was built across the road and attached to the school. The construction and running of the school were highly appreciated by members of the community, as confirmed in the following remark:

“... when we were all young and there was no schooling there, he was able to build a school. He specially built a school for the Goans and he manned it with teachers from England, he got the headmistress from England. A lot of Goan teachers were teaching as well so he did give employment to a lot of young women who came out $[\ldots]$ and he persuaded them to teach." ${ }^{\prime 37}$

\section{Political Life}

In the early years of Goan migration to East Africa, Goans seem to have interacted freely with Indians, Europeans, and Africans. There is a general emphasis on the fluidity of economic and social life of South Asians in East Africa before the First World War, which allowed for diverse responses to economic opportuni$\operatorname{ties}^{38}$. However, the increasing segregation of society implemented by the British colonial government called for concentration on the community. By the late $1910 \mathrm{~s}$, it appears that Goans interacted socially for the most part with members of their own community only. The most sensitive issue here was marriage. Almost no one married outside the community, and even within the community itself, a certain etiquette had to be followed. Goans often resented being classified as 'Indians' since Goa was seen as a Portuguese colony (until 1961). From about the 1950s on however, both Goans and Indians were summarised under the category 'Asians' when it came to colonial policy.

Up to the early 1950s, interaction with 'Europeans' was largely restricted to the professional arena, particularly in Kenya. The story told by one interviewee seems symptomatic: in vivid terms, he recounted how the friends he had made during his studies in the United Kingdom (UK) would not look at him as soon as they had boarded ship to East Africa, and warned him not to visit them at their houses once they reached Nairobi. At the time, interaction with Africans was also limited to the working environment and to cases where Africans were employed as servants in the household ${ }^{39}$.

Structural economic and political differences in the countries of East Africa prompted varying responses in Goan communities. The latter had managed to carve out social, economic and political spaces with specific Zanzibari, Tanganyikan, Kenyan or Ugandan characteristics ${ }^{40}$. The movement between the intersecting local contexts is nicely illustrated by sports events, which acted as a link between

\footnotetext{
${ }^{37}$ Interview with Charlotte, UK, March 2006.

${ }^{38}$ M. Twaddle, "Was the Expulsion Inevitable?", in M. Twaddle (ed.), Expulsion of a Minority: Essays on Ugandan Asians, London, University of London, Athlone Press, 1975: 1-14.

${ }^{39}$ Interview with Samuel, Kenya, August 2006.

${ }^{40}$ This argument could be made for the Goans in Mozambique who had carved out economic, social, and political niches for themselves (personal communication Antonia, Goa, December 2002).
} 
the different East African Goan spaces. The link to Goa was in turn maintained by schooling and regular visits. In the political domain, the prevailing ideas of the freedom movement in India had an impact on the nationalist movement in East Africa. The building of institutions such as clubs, churches, and schools influenced the formation of a Goan community identity. Specific characteristics relevant to the local context were attributed to the respective communities, e.g. Nairobi Goans were perceived by other East African Goans as 'sophisticated'. Far from being contained, these social spaces were open to change and transformation. Overall, the Goans seem to have 'comfortably institutionalised' themselves in professional and social niches in East Africa.

This 'institutionalisation' is another key characteristic of the translocal time layer. It emerges out of and is a parallel process to the migration movement which still continues. The constant exchange between the different localities across the Indian Ocean and within East Africa in economic, social and political terms exemplify the flow of people, goods and ideas in the political framework of the British Empire. The simultaneity of movement and institutionalisation are aptly illustrated by the Goan case: the migration to East Africa and the individual experiences of sports competitions, for example, and the establishment of community-wide institutions such as the church, club, and school happened at the same time. However, the political situation changed dramatically in the 1960s, and thus, required adjustments.

\section{Leaving Familiar Shores: On the Move Again}

When independence in East Africa was achieved in the early 1960s, nation-states with new international boundaries came into being, severely limiting the mobility of Goans in the process. At the same time, the newly elected post-colonial governments pursued policies that curtailed the economic and political role that Indians and Goans had been allowed to play within their 'host' societies. Thus, new social and economic fault lines emerged, along which inclusion and exclusion were practised.

Zanzibar gained independence on 10 December 1963. However, the Sultanate of Zanzibar was short-lived. After the revolution of January 1964, the Sultan was overthrown and three months later, Zanzibar merged with Tanganyika to form a republic. This experience was traumatic for the Goan community, since a few Goans were killed on their way home from church during the first days of the revolution. As a result, the community became exceedingly apprehensive about its future. In the months that followed, the Revolutionary Government of Zanzibar and Pemba nationalised the land, all immovable property, and import export trade. With rare exceptions, government posts were 'Africanised'. The economy took a dramatic downward turn, while jobs and business opportunities were severely restricted. Consequently, many Goans fled the island. It appears that of all the East African locations, Zanzibar was to lose the most Goans and Ismailis ${ }^{41}$.

In 1961, Tanganyika celebrated its independence by lighting the symbolic Uhuru torch on Mount Kilimanjaro. In April 1964, Julius Nyerere and Abeid Karume

${ }^{41}$ Personal communication with Abdul Sheriff, Tanzania, July 2005. 
agreed to establish the United Republic of Tanzania, with Nyerere as president and Karume as vice-president. Life in mainland Tanzania did not change as dramatically as in Zanzibar. Nevertheless, the revolution in Zanzibar and its aftermath had created an atmosphere of anxiety and mistrust ${ }^{42}$. The passing of the Arusha Declaration of 1967 made professional life for Indians difficult as it nationalised properties and introduced restrictions on work permits. The latter had to be renewed either annually or every two year for a considerable fee. These mounting obstacles in professional and social life led many Indians and Goans to the conclusion that it was time to move on.

Kenya became independent in 1963. Although some Indians and Goans had actively supported the nationalist movement, their role in the new independent Kenya remained insignificant. The most prominent Goan politicians in the country were Pio Gama Pinto (1927-1965) and Joseph Murumbi (1911-1990), who became the second vice-president of Kenya. Pio Gama Pinto was shot in 1965, the first victim of a series of political assassinations in Kenya ${ }^{43}$. Coupled with the shock this caused in the Goan community was the growing complexity of their economic situation. The Trade Licensing Act of 1967 excluded Indians from engaging in business in certain commodities and areas, and affected about $60 \%$ of the Kenyan Indian population. However, this act did not have the desired effect of pressurising Indians into leaving Kenya, because it was counterbalanced by the UK Commonwealth Immigration Act of 1968 (see below). Hence the Kenyan government adopted an additional legislation in 1974, eroding even further the position of non-citizen British Indians. Importantly, Indians were badgered into giving up their administrative posts by a gradual but firm policy of 'Africanization'. By the late 1970s, the post-colonial government had almost succeeded in removing both Indians and Goans from senior administrative positions ${ }^{44}$. Moi's coup in 1982 gave rise to further apprehension in the community, and prompted a number of Indians, including Goans, to leave the country.

Uganda attained independence in 1962. The transition to an independent government seems to have had little affect on Indians and Goans in their daily lives: they felt they had a place in Ugandan society and its economy, since quite a few Goans served in higher government positions and in the army. ${ }^{45}$ However, their way of life was to undergo an abrupt change when Idi Amin seized power in early 1971. On 4 August 1972, Amin issued an order requesting all Asians who had not taken out Ugandan citizenship to leave the country within three months. With this move, Amin intended to regain popular legitimacy, because it was widely believed at the time that Asians merely 'exploited' Africans. By the end of 1972,

\footnotetext{
42 Interview with Sebastian, Tanzania, June 2006.

43 See M. Frenz, "Swaraj for Kenya", ms., British Institute in Eastern Africa, London, March 2007.

44 Interview with Samuel, Kenya, August 2006. In the ten years between the Census of 1969 and of 1979, nearly 50\% of Asians left Kenya (Ministry of Economic Planning and Development, Population Census 1979, Nairobi, Central Bureau of Statistics, 1981: 36.

${ }^{45}$ Interview with Robert, UK, November 2004 and with Michael, Goa, January 2006.
} 
no more than a handful of Goans, who had managed to get an 'exemption stamp' on their passports, were left in Kampala ${ }^{46}$.

\section{Citizenship and Passport Issues}

The issue of citizenship had become a crucial factor in the post-colonial East African setting. Holding the 'right' passport was imminent when it came to deciding whether to stay or to migrate again. The issue was further complicated for Goans in 1961 by the inclusion of Goa into the Indian Union. Those who lived in East Africa and who had possessed a Portuguese passport up to that time were asked to surrender it to the Indian High Commissioner. They were obliged to make a decision on whether to apply for an Indian or a British protected passport. When the countries of East Africa gained independence, Goans once again found themselves confronted with a citizenship decision, this time whether to take up Tanzanian, Kenyan, or Ugandan citizenship and thus maintain their residential status and work permits in the respective country. A significant number of Goans opted for protected British status, thinking that this might open up job opportunities and present their children with the prospect of a sound education in the UK. Obtaining protected status as a British subject, however, failed to deliver the advantages they had hoped for. New UK immigration laws passed in the late 1960s and early 1970s limited Goan and Indian access to the UK, even for those who were British protected subjects.

Commonwealth citizens travelling to the UK had faced restrictions for the first time in 1962, when the Commonwealth Immigration Act imposed stronger immigration controls. British passports were classified in different status categories according to the place of issue. Holders of passports issued by the UK government were permitted free entry to the UK at any time, whereas entry was restricted for those with passports issued by colonial governments. The same applied to 'protected persons' and Irish citizens. As a result, citizens of the UK and colonies who were of Indian descent lost their right of entry to the UK Additionally, a three-tier voucher system for work permits was introduced ${ }^{47}$. The subsequent Commonwealth Immigrant Act of 1968 subjected UK passport-holders outside the British Isles to immigration controls - unless the passport-holder or a parent or grandparent had been born, adopted, or naturalised in Great Britain or a Commonwealth country that was self-governed by 1948. On the face of it, this act merely laid down certain qualifications for the acquisition of UK citizenship,

${ }^{46}$ Probably, only seven Goans remained in Kampala (various interviews, Uganda, June 2006). A similar phenomenon can be observed in Portuguese East Africa: Following independence in Mozambique, many Goans left. They mainly went to Portugal. This decision was heavily influenced by questions of citizenship and language. Interviews with Mona, Tom, Peter, Goa, December 2005. However, some Goans perceived themselves as Mozambican rather than Portuguese and decided to remain in Mozambique (personal communication Simon, Goa, December 2002).

${ }^{47}$ For Indians specific rules applied: UK passport holders of Indian descent in newly created Commonwealth Countries of Africa, whose passports had been issued by various British High Commissions on behalf of the British Government still were given free entry to the UK. 
'but the real purpose of this provision was to deprive the British Asians of their right of entry on racial grounds ${ }^{\prime 4}$. Thus, although British protected subjects legally remained citizens of the UK and colonies, in practice, they lost their status as citizens. In addition, entry vouchers were introduced, a maximum 1,500 of which were issued annually. A further erosion of the rights of Commonwealth citizens came with the 1971 Immigration Act, which distinguished between 'patrials' and 'non-patrials'. The latter were subject to entry controls and employment restrictions, and were threatened by the possibility of deportation ${ }^{49}$.

The combination the policies pursued by newly established governments in East Africa, India, and the UK strongly influenced migration patterns in the 1960 s and 1970s. The passing of immigration laws that placed people in different status categories acted as a regulatory force to channel the movement, institutionalisation and circulation of people ${ }^{50}$. Newly drawn boundaries restricted hitherto open routes of movement across the Indian Ocean between India and East Africa, and beyond to other countries. Independence and its consequences in the countries of East Africa and the new immigration laws in the UK transformed local realities considerably. The creation of nation states and the associated legislation, particularly the question of citizenship and passports, marks the shift to the transnational layer. Newly emerging social, political, and economic fault lines meant that the niches Goans had carved out for themselves during the colonial period had now become more slender, some even vanished completely. Hence the space occupied by Goans in Tanzania, Kenya, and Uganda was more and more confined, which in turn hindered the income-generating activities indispensable to making a living. Furthermore, the revolution in Zanzibar in 1964, the expulsion of Asians from Uganda in 1972, and the coup in Kenya in 1982 created an atmosphere of apprehension in the community. This tension correlated with the concentration of Goans on the family, rather than the community. In order to survive, or to find a new means of livelihood, family resources were pooled. However, since families chose individual coping strategies based on their respective circumstances, ties in the community were loosened.

\section{A Blessing in Disguise': Making a New Life}

The narrowing down of professional and social niches prompted Goans to move to other countries. Goan migrants dispersed to an increasing number of localities, where families were spread across different countries and, if in the same country, more often than not in different locations of the big cities. Demands on education

48 A.P. Lester, East African Asians Versus the United Kingdom: The Inside Story, Lecture, London, 2003, 19 p.: 4, based upon A.P. Lester, "Thirty Years On: The East African Case Revisited", Public Law, 2002: 52-72.

${ }^{49}$ Canada and other countries in the 'western' world followed their own agendas and regulations that shaped the process of migration to those countries. For a self-perception of Goans and Indians from Uganda in Canada, see N. WAGLe, et al., Uganda South Asians Exodus: Kololian Perspectives, Toronto, University of Toronto, 2002, 95 p.

${ }^{50}$ See R. Ahuja, et al., Indischer Ozean - Transformation einer Seascape, proposal to the Deutsche Forschungsgemeinschaft, Berlin, $2002 \&$ 2003, (unpublished). 
and professional life emphasised the individual rather than the family. In short, Goans were concerned with getting their lives back on track and establishing themselves in yet another local context, but now no longer within the framework of the community. Although at the time Goans were forced to migrate from East Africa, in their current perception, this move was 'a blessing in disguise', since it opened up new educational and professional opportunities ${ }^{51}$.

The Goans who came from East Africa primarily settled in Goa, the UK, Canada, the United States, Australia, New Zealand, Brazil, and Portugal, as well as in other countries of Europe and the Americas ${ }^{52}$. A certain pattern or at least a migration trend can be discerned. Whereas the majority of Goans from Uganda moved to Canada, the UK seemed to have possessed more appeal for Kenyan Goans. Goans from Tanzania divided themselves more equally between the two, and Australia. The UK and Canada were seen as having greater economic opportunities than Portugal or Goa. When their passport and citizenship allowed, these countries were their choice. A small minority of Goans decided to stay in East Africa. As mentioned above, only a handful continued to live in Kampala. Today, there are about fifty Goans in Uganda, about 800 in Kenya, 500 in Tanzania, and one hundred in Zanzibar. Interviews and personal discussions with members of the respective communities suggest that the number of Goans living in East Africa will decline even further ${ }^{53}$. The phenomenon of the worldwide circulation of the Goan community along with resumed and intensified communication is considered as a feature of the global temporal layer.

\section{The United Kingdom}

Goans settled throughout Great Britain, but mainly in the greater London area. It is difficult to estimate the exact numbers of Goans residing in the UK, because the census summarises under the category of 'South Asians'. A few tentative figures might give an impression: In 1972, approximately 28,000-29,000 Asians arrived in the UK from Uganda, amongst them Goans ${ }^{54}$. In the late 1970s, the Goan community decided to conduct a survey of Goans living in the greater London area. The survey established that approximately 5,000 Goans lived in London at the time. However, it did not include any other location in the UK, and does

51 The majority of Goans interviewed who migrated to the UK and to Canada emphasised this point of view.

${ }^{52}$ Goans moved to Portugal from Mozambique and Angola, but also directly from Goa (the number of Goans in Portugal is estimated at approximately 50,000). They are to be found in a variety of professions and established associations such as 'Casa de Goa', 'Tertulia Oriental' and others. Interview Mona, Tom, Goa, December 2005. For Goans in Brazil, see L. Pinto Teixeira, "Destino: Brasil. Os goeses de São Paulo, 1961-2005", Africa e o Índico. Histórias conectadas e dinâmicas pós-coloniais, forthcoming.

${ }^{53}$ Interviews and personal communications with the chairpersons of the Goan associations in Tanzania, Kenya, and Uganda, June, July, August 2006.

${ }^{54}$ W.G. Kuepper, G.L. Lackey \& E.N. Swinerton, Ugandan Asians in Great Britain: Forced Migration and Social Absorption, London, C. Helm, 1975; N. van HeAR, "Editorial Introduction to the Ugandan Asian Theme Papers", Journal of Refugee Studies (Oxford), 6 (3), 1993: 226-229. 
not claim to be comprehensive for London either. Moreover, 80\% of the respondents worked in 'white collar' jobs. It should also be emphasised that many Goans had to start afresh or work in lower positions than they had done prior to migration to the $\mathrm{UK}^{55}$.

Today, Goans are found in almost any professional field, from hairdresser to university professor, information technology specialist and finance genius in the city of London. In contrast to colonial East Africa, all professions were open to them; the elites were able to rise to greater heights. Taking the British census of 2001, it is striking that the British South Asian community, under which Goans are subsumed in this country, is a comparatively well-educated group.

Several attempts were made to restart community life in the 'East African' style. The Goan Overseas Association (UK), which was founded in 1962, acts as an umbrella organisation to all village associations established in London during the 1960s and 1970s, as was the case in East Africa. The Goan Overseas Association (UK) Standing Committee on Race Relations and Immigration was established in 1976 to support members of the Goan community who came from East Africa to the UK. The Goan Overseas Association (UK) and the village associations organised feasts and other social gatherings, such as dances and sports events. The clubhouse, which was bought in the 1970s, burnt down in the 1980s, but was not replaced. Goan Overseas Association (UK) events now take place in rented venues in North and South London. However, club life did not take off as vigorously as in East Africa. This was due to several factors, amongst them the perceived need to carry on with one's own life, adapt to working life, and make a living in the new location. Without exception, all my interview partners spoke of their difficulty in adjusting to the UK. The 'cold and unfriendly' climate in the UK was mentioned as a major problem that greatly hindered an outdoor life and as a result, restricted interaction. Sometimes, the climate was used as a metaphor for the difficulty in finding new friends. Numerous respondents talked of their homesickness, at least during initial years of residence in the UK. Since Goans are widely dispersed, they tend to become integrated in the area they live in, e.g. children go to sports clubs at their school or in their neighbourhood instead of attending the Goan Association sports club. Social events still take place, but not as frequently as in East Africa or during the early years in the UK. This also led to the opening up of the community and a stronger integration in UK society. In turn, caste as an identity marker in social interaction between members of the Goan community lost almost all significance and is mentioned only rarely and with reluctance. It comes subtly to the fore, however, when individuals ask each other about the village of their forefathers. Social control is less effective where the community is wide spread - in contrast to the situation in East Africa where the community lived a somewhat closed life ${ }^{56}$.

55 S.V. Mascarenhas-Keyes, Goans in London, Portrait of a Catholic Asian Community, London, A Goan Association (UK) Publication, 1979.

56 Interview with Lucas, Susan, Sabrina, Tanzania, July 2005. 


\section{East Africa}

Goans who had decided to stay on in East Africa for various reasons ${ }^{57}$ had to adjust to a new political and economic local context connected with the establishment of nation states. Today, the situation seems to be reasonably 'peaceful' in all the East African countries - with the possible exception of Zanzibar, where the political situation appears unstable and therefore unattractive for a significant number of people I interviewed ${ }^{58}$. Many Goans in East Africa work in information technology, as engineers, managers, or have their own businesses. They tend to send children to be educated abroad in order to equip them with a firm base - and therewith, professional opportunities currently not available in East Africa. Consequently, many of these children made the decision to stay in the countries they were originally sent to for higher education, where they had now found jobs, and often partners. In turn, a number of the parents considered moving closer to their children after their own retirement. This trend was obvious at least for Zanzibar, Tanzania, and Kenya, and will diminish the Goan community in East Africa in due course. The situation in Uganda is slightly different, as only a handful of the 'original' Goans still live there. A few more have come to work in Uganda in the past decade. They are either bachelors or have very young families. Several attempts have been made in recent years to build a bridge between the Goan communities in Uganda, Kenya, and Tanzania. Spearhead of this idea are the East African Goan Conventions, the first of which took place in 1999. Goans from across East Africa, and occasionally from 'abroad', meet at regular intervals. The conventions are supplemented by 'national' meetings in the interim years. The main aim of these gatherings is to foster mutual support in the community, especially for the elderly, and to initiate sports competitions for the youth ${ }^{59}$.

From the 1960 s to the 1980 s, the majority of Goans was busy settling in to their new local contexts, becoming established and institutionalised. A new interest emerged in the 1990s - Goa. Notwithstanding the country they live in, the interaction of East African Goans in the last decade has more often and more intensely been engaged with their ancestor's country of origin. Apart from families who try to sort out issues regarding their ancestral property, this is perceived to be an individual undertaking. Goa has now become a popular holiday destination among more affluent Goans from the UK, Canada, the USA, and Australia. The increase in contact between East African Goans can also be seen in the 'school reunions', which serve as a nostalgic meeting point and have gained new currency. Get-togethers are now a fairly regular phenomenon. So far, most of the reunions

${ }^{57}$ Many Goans perceived East Africa as their home. Some families had lived there for two, three or even four generations. See M. Frenz, Moving Home, Settling In. Cosmopolitan Goans in Zanzibar, ms., Zanzibar, July 2005 and M. Frenz, Global Goans. Circulating Home in an Imperial and Post-Imperial World, ms., University of Oxford, May 2005.

${ }^{58}$ This article was written before the elections in Kenya in December 2007. The precarious situation after the 2007 elections might dramatically change the circumstances of Goans in East Africa.

${ }^{59}$ Other Indian communities, particularly the Ismailis, are often quoted as examples (interviews with Adelina, Kenya, August 2006, Tim, Tanzania, June 2006). 
have taken place in Canada ${ }^{60}$. Again, the emphasis is on the individual rather than on family or the community. Another event that intends to connect Goans worldwide is 'World Goa Day', which was created in 1999. It is celebrated on or around the 20 of August each year and seems to have gained popularity with Goans across the globe ${ }^{61}$.

Settling down in the new local contexts of the UK, Canada, and other countries of the 'western' world has had its impact on the constitution of Goan families and the community. Interaction between individual members of the community was condensed and accelerated by the worldwide web. Other geographical local contexts were added to those already in existence. A new time quality emerged - the global temporal layer. There was a shift in emphasis from a transnational to a global layer. Correlated with the social unit, this trend indicated a shift towards the individual, although family, and to a lesser degree, the community still carry considerable weight.

The present case study on migration movements of Goan families across the Indian Ocean and beyond it in the late nineteenth and most of the twentieth century argues for the conceptualisation of migration movements in a historical perspective. The translocal, transnational, and global layers were identified as the most significant temporal layers. Since the late nineteenth century, Goans have moved between a growing number of local contexts, i.e. Goa, East Africa and several countries in the northern hemisphere. Their movement, institutionalisation and circulation took place across all three temporal layers. Importantly, these temporal layers do not occur in linear sequence, but overlay and intersect each other. Issues surrounding passports and citizenship clearly illustrate the shift from locality to nation states and the regulatory mechanisms they employ, which in turn influence decisionmaking processes of families and individuals, as witnessed in the second migration of Goans from East Africa.

Specific space-time relations arguably correspond to specific forms of social interaction. In the Goan case, it can be argued that corresponding to the translocal phase - approximately the late nineteenth and early to mid-twentieth century social interaction primarily focused on the Goan community; corresponding to the transnational phase, which began in the $1950 \mathrm{~s}$ - social interaction tended to concentrate on the family, as the community had lost much of its appeal; corresponding to the third - global - phase, from the 1980s onwards, social interaction

${ }^{60}$ For instance, the St Joseph's Convent School of Zanzibar Reunion in Canada in 2006 attracted a few hundred Goans from all over the world. Another reunion of this school is scheduled to take place in Goa in 2008. The Dr Ribeiro Goan School Nairobi holds regular reunions in Toronto.

61 'World Goa Day' was introduced by a Goan of London in 1999. The aim is to "mark a day in the year where Goans, globally, would come together in solidarity with Goa and Goans. The day honours the vibrant history, language, music, cultural heritage and traditions of Goa" (personal communication with Xavier, March 2004). Recently, the World Alliance of Goan Overseas Associations has been established in order to link the various Goan Associations worldwide and support the organisation of 'World Goa Day'. 
seems to have revolved around individuals, since both family and community were no longer seen as the main arena for identity formation. Again, it should be stressed that these layers do not succeed each other in a linear fashion, but overlay each other. Thus, it is still possible to speak of a Goan community or a Goan family as meaningful social entities. Their importance, however, has declined significantly.

Goan identity was constructed in the context of their twice migration in the translocal, transnational, and global temporal layers. It was shown how important social institutions, i.e. the church, clubs and schools, were to the Goan community in the translocal phase. They continued to be meaningful as a point of reference. However, in later years, there was a shift in emphasis towards the family, and finally, to the individual. These developments corresponded with the transnational and the global layers of Goan migration. Arguably, the link between migration movements and identity formation can be applied to other migratory groups with a similar history. 